\title{
Comment: Chocolate, Coffee and Commodity History
}

Jonathan Morris, School of Humanities, University of Hertfordshire, UK.

\begin{abstract}
This comment considers the history of chocolate in parallel with that of coffee, in order to identify not only patterns of similarity and distinction, but also to highlight potential strategies for explanation and their implications for the writing of commodity history.
\end{abstract}

\section{Keywords Cacao, Chocolate, Coffee, Commodity History}

The appearance of this new collection of primary research articles on aspects of the history of chocolate affords an opportunity to reflect on possible approaches to the integration and implications of their findings into an overview of that history as a whole. By considering these in parallel with the history of coffee, it may be possible to identify not just patterns of similarity and distinction, but also strategies of explanation with implications for the writing of commodity history.

Coffee and chocolate share many similarities as crops, commodities and consumer products. Both crops can only be grown in the tropics, in both cases the tradable commodity takes the form of a dry bean, and in both instances that bean has to be roasted and subject to various additional processes in order to turn it into a consumable. The final coffee and chocolate products have frequently had their connections back to their origins obscured-, enabling them to be recast as branded "glocal" goods; өnes-that have been both materially adjusted and culturally constructed to respond to the particular preferences of the eventual consumer. That disconnection has been intensified over the course of a historical trajectory that has seen both coffee and chocolate travelling the path from elite luxuries to democratised daily indulgences within the developed nations of the West.

Comparing the histories of chocolate and coffee highlights some revealing points of contact and contrast along these trajectories. It is well known that coffee entered Europe from the Ottoman Empire via Venice - much less so that the Venetians, as Köse shows, were probably the first to introduce chocolate to the Turks. This forgetfulness is, in part, because the consumer community - in this case composed of the foreigners attached to the Sultan's court - have themselves faded from memory: the same is true of the British imperial community which, as Frasch indicates, constituted the market for the first chocolate factory in Ceylon. Ceylon was also one of the sites where one crop succeeded the other when the inland coffee plantations that briefly became the biggest source of world supplies in the mid- $19^{\text {th }}$ century were wiped out by the coffee rust virus, and a small portion of these were replanted with cacao (the majority, of course, switching into tea). For the most part, however, coffee and cacao have complemented each other with cacao more suited to lowland production, and coffee favoured for the cooler temperatures of the uplands.

After the demise of the Ceylon plantations, coffee, although native to Africa and first cultivated in Arabia, became principally a Latin American commodity, whereas cacao, although indigenous to Latin America and first cultivated in Mesoamerica, became a predominantly African export after $1920^{1}$. There is no escaping the fact that the diffusion of

1 Robin DAND, The International Cocoa Trade (Cambridge, 1999), pp.1-20 provides a short overview of the history of the cocoa trade that traces the shifts in the centres of production. For a similarly compressed history of coffee see Jonathan MORRIS, "Coffee: A Condensed History" in Robert THURSTON, Jonathan MORRIS,

\begin{tabular}{|l|}
\hline Formatted: Font: $10 \mathrm{pt}$ \\
\hline Formatted: Font: $10 \mathrm{pt}$ \\
\hline Formatted: Justified \\
\hline
\end{tabular}


both crops across the tropics was primarily the outcome of colonisation and coercion - be it through taxation systems, transfers of land ownership and, in many instances, unfree labour. As Tous shows, even in those regions of Mesoamerica, in which cacao had been cultivated prior to the arrival of the Spanish, its increasing popularity in the European market led to fundamental transformations of landholding structures and societal composition, which that undermined ing the collective identities and institutions of the native population. Brazil's coffee and cacao trades were built on the back of slave labour, with it and other Latin American nations retaining their systems of unfree labour for some time after independence, enabling them to remain the world's principal source of both coffee and cacao during the nineteenth century. Commentators have argued that the European colonial powers preferred to obtain their coffee on the open market as they recognised they could not match the ruthlessness with which the Latin American producers exploited their own citizens².

The real take-off in both cocoa and coffee consumption took place towards the end of the nineteenth century, however, following the legal abolition of slavery, and principally as a result of the massive expansion in the market in the United States. Why, then, did coffee production become so increasingly concentrated in Latin America in general and Brazil in particular (the source of 80 per cent $\%$ of the world coffee supply in 1906) during this period, whereas the continent's virtual monopoly of the global production of cacao until the 1880s was progressively ceded to West Africa thereafter?

The answer lies not so much in economic as ecological history. The devastation of the old world coffee growing regions by coffee rust saw African and Asian production fall from around 33 per cent $\%$ of world production in the 1850 s to just 5 per cent $\%$ by $1914^{3}$. Brazil was left virtually unchallenged in being able to produce and process high volumes of low grade coffee, exploiting its easy access to fresh fertile supplies of land, its relatively developed internal transport links and its proximity to the principal markets in the US, to the point that it was able to afford to attract significant numbers of immigrant labourers from Southern Europe to bolster the native workforce ${ }^{4}$.

In the case of cacao, however, the increasing cultivation of the hardier, albeit poorer quality forastero variety, facilitated its spread as a bulk commodity crop outside the South American continent with the British, French and German colonies in West Africa all adopting the bean, along with the Portuguese on the islands of Sao Tome and Principe, which became the world's principal source of supply in the 1900s. This reflected the strategy of Portuguese planters and colonial authorities to gradually relocate their business across the Atlantic in order to preserve their de facto access to unfree labour ${ }^{5}$. On the mainland, however, slavery was superseded by other forms of contract labour, albeit subject to equally horrendous working conditions. Ultimately the high real costs of labour and low levels of productivity associated with the plantation system saw this progressively abandoned to cultivation by peasant small holders who proved much more efficient in their occasional employment of additional labour: even the

Shawn STEIMAN (eds.), Coffee: A Comprehensive Guide to the Bean, the Beverage, and the Industry (Lanham, 2013), pp. 215-225.

${ }_{4}^{2}$ Steven TOPIK, "The Integration of the World Coffee Market" in Steven TOPIK, William Gervase CLARENCE SMITH (eds.), The Global Coffee Economy in Africa, Asia, and Latin Ámerica 1500-1989 (Cambridge, 2003), pp.29-30.

${ }_{3}^{3}$ Stuart MCCOOK, "Global rust belt: Hemileia vastatrix and the ecological integration of world coffee production since 1850", Journal of Global History, vol. 1, no. 2 (2006) 1, pp. 177-195.

${ }^{4}$ Steven TOPIK, "IIntegration of the World Coffee Market'...", pp.31-36 analyses the reasons behind Brazilian dominance.

${ }_{5}^{5}$ Timothy WALKER, "Establishing Cacao Plantation Culture in the Atlantic World: Portuguese Colonial Cacao Cultivation in Brazil and West Africa, c. 1580-1912," in Louis GRIVETTI and Howard SHAPIRO (eds.) Chocolate: History, Culture and Heritage (Hoboken, 2009), pp. 543-560.

\begin{tabular}{|l|}
\hline Formatted: Font: $10 \mathrm{pt}$ \\
\hline Formatted: Font: $10 \mathrm{pt}$ \\
Formatted: Font: $10 \mathrm{pt}$ \\
Formatted: Font: $10 \mathrm{pt}$ \\
\hline Formatted: Font: $10 \mathrm{pt}$ \\
Formatted: Font: $10 \mathrm{pt}$ \\
Formatted: Font: $10 \mathrm{pt}$ \\
\hline
\end{tabular}


much vaunted Viktoria plantation in the Cameroon depicted in Hacekenesch's contribution had been converted into small holdings by $1920^{6}$.

A post-script to this ecological history is that Africa and Asia later recouped some of their role in the coffee economy by turning to the similarly hardier, but lower quality, robusta species, which today accounts for 35 to -40 per cent $\%$ of world production. It is through the extensive cultivation of robusta that Vietnam has achieved its phenomenal rise over the course of the last two decades to become the world's second largest coffee producer, in part provoking the crisis of over-supply that led to the collapse in green coffee prices during the early years of the $21^{\text {st }}$ century ${ }^{7}$.

The relationship between production and consumption of a foodstuff is more complicated than the simple balance between supply and demand, however, because of the necessity of transforming the commodity into a comestible. Often the final consumer themselves assumes responsibility for this transformation through cooking. As Rachel Laudan has recently reiterated, this raises important issues of causation within commodity studies in that the process by which global foodstuffs are transferred into new markets are principally conditioned by local cultures of culinary philosophy and practice ${ }^{8}$.

In the cases of chocolate and coffee, much of the considerable work of preparation prior to consumption (roasting, pressing, grinding etc.) that was originally undertaken if not by the end consumer then by the final provider - such as the coffee houses and chocolate cooks of the early modern era; was transformed into an industrial process over the course of the $19^{\text {th }}$ century. This undoubtedly facilitated a "democratisation" of access to coffee and chocolate, but at the same time augmented the material and mentally "distance" between the original bean and the eventual product, because of fundamental changes in the way the latter was both constructed for popular consumption. As Robertson points out, this was even true for workers in chocolate factories themselves.

The technological innovations in the production of chocolate have been recounted in several of the contributions to this volume. Perhaps what needs emphasising is that not only did the invention of the Van Houten press, the alkalisation process, the combining of milk powder with cocoa butter ${ }_{2}$ and the development of the conching technique all lead to significant changes in the form of chocolate - notably the development of the solid, edible, bar; they were also, as Ellenbrook argues, drivers for a scaling of production that benefitted from mechanisation and electrification, and resulted in an increasing concentration of production within large companies, albeit that these were spread fairly evenly in terms of their location throughout Germany (as was also true of the major British producers: Fry's in Bristol, Cadbury in Birmingham, Rowntree in York). Operating at such a scale enabled them to access and benefit from the new forms of distribution developing in the same period - such as chain stores and multiples - while solid chocolate products were particularly suited for sale through the newly developing vending machines.

Progress in the coffee industry was driven less by changes in the product itself than through the scaling of the machinery used to prepare it. The Emmericher Maschinenfabrik \& Eisengießerei van Guelpen, Lensing \& von Gimborn founded in Emmerich in 1868 - today known as Probat - began producing roasting machinery in the 1870s of sufficient size to

${ }^{6}$ William Gervase CLARENCE SMITH, "Cocoa Plantations and Coerced Labor in the Gulf of Guinea, 1870 1914" in Martin A KLEIN, Breaking the Chains: Slavery, Bondage and Emancipation in Modern Africa and Asia, (Madison, 1993) pp.150-170; William Gervase CLARENCE SMITH, Cocoa and Chocolate, 1765-1914 (London, 2000), pp. 195-226.

${ }^{7}$ Robert THURSTON, "Vietnam" in Robert THURSTON, Jonathan MORRIS, Shawn STEIMAN (eds-), Coffee: ${ }_{4}^{7}$ Robert THURSTON, "Vietnam"
A Comprehensive Guide, 158-61.

${ }^{8}$ Rachel LAUDAN, “Afterwood” in Benjamin N LAWRANCE, Carolyn DE LA PENA, Local Foods meet Global Foodways. Tasting History, (London, 2012), pp. $20 \overline{3}-\overline{2} 10$.

Formatted: Highlight

Formatted: Font: Italic

Formatted: Font: $10 \mathrm{pt}$

Formatted: Font: $10 \mathrm{pt}$

Formatted: Font: $10 \mathrm{pt}$

Formatted: Font: $10 \mathrm{pt}$

Formatted: Font: $10 \mathrm{pt}$

Formatted: Font: $10 \mathrm{pt}$ 
effectively allow the individuals operating it to set up a full time business roasting coffee and supplying this to grocers on a local scale, whereas before coffee had tended to be supplied green or roasted in the store prior to purchase ${ }^{9}$. The scale of such operations increased as a result of improvements in both roasting technology and packaging techniques, but still operated on a largely local level well into the $20^{\text {th }}$ century.

The democratization of coffee was principally achieved not through access to the beverage itself, but rather via the various surrogate products that appeared on the market from the late $19^{\text {th }}$ century such as "Camp Coffee" - a coffee essence and chicory product produced by R Patterson in Glasgow, and Caffeol and Moretto, the chicory, chick-pea and molasses extracts manufactured by Craston in Italy ${ }^{10}$. The durability of these products and their much simpler packaging requirements made them much easier to produce, distribute and market on a volume basis than roasted coffee itself.

The marketing strategies adopted by the chocolate and coffee industries also reflected the ways in which the developments within the manufacturing process had served to further distance the end products from their origins. Using beans from various sources enabled producers to avoid becoming dependent on the vagaries of supply from a particular region, instead blending them together to produce a consistent tasting product. The identity of that product was conferred principally through branding which, particularly in the case of chocolate, often drew less on the origin of the bean than on the "national" origins of other components such as milk, most notably in the case of Suchard's Milka, or Cadbury's Dairy Milk. This, combined with the differences in the employment of techniques such as conching and the variations in the kind and extent of additives used in different markets, created a set of national industrial chocolate styles (e.g., Belgian and Swiss chocolate) that built on the earlier differences in national flavouring preferences noted by Schulte-Beerbuehl. Interestingly, as these branded products moved into international markets they were tweaked to fit to national tastes so they too assumed a "glocal" character"11.

Where branding referenced the tropical origins of the product, this was now constructed within a colonial and racial discourse that perhaps served to reassure consumers not just about the qualities of the product, but about their place in the world order per se. It is revealing that the Sarotti Mohr character with its unthreatening, docile, attributes originated at a time of considerable fear of the "racialised other" occasioned by the use of black troops in the French occupation of the Rhineland, and that it should be remobilised during the post-second world war era when consumers were striving for a return to a normality that no longer existed. Yet, while the Mohr may have evoked a disappearing era in which the middle class could afford servants, it also spoke to the new characteristics of the confectionary market in which children had become a key segment.

It is easy to find parallels to the Mohr amongst other products and places. In Britain, the golliwog doll, a similarly stereotypical black minstrel-like figure, became popular during the early_-twentieth century and was adopted as the emblem of the jam manufacturer James Robertson and \& Sons in 1910 - a role in which it survived until $1988^{12}$. The golliwog was based on a character from children's literature described as "brave, courteous and lovable" -a similarly unthreatening depiction of the black other that was, perhaps, comforting during the

${ }_{9}^{9}$ Carl Hans von GIMBORN, “Zur Geschichte der Kaffeerösttechnik” in PROBAT-WERKE, Museum für kaffee technik (Emmerich,1993). See also http://www.probat.com/en/company/on-probat/company-history.html accessed 1 Nov 2012.

10 Jonathan MORRIS, “Making Italian Espresso, Making Espresso Italian”, Food and History, vol. 8, no. 2, 2010 p.167. http://www.crastan.it/pagina_template.asp?id=2\&pag_A $=6$ \&lingua=ITA accessed 1 Nov 2012;.

${ }_{11}$ Régis HUGUENIN, "Milka, 1901-1990: vers un goût international de chocolat”, Food and History, vol.8, no. 2, 2010, pp.93-118.

12 Miranda KAUFMANN, “Golliwog” in David DABYDEEN, John GILMORE and Cecily JONES (eds.), The

Oxford Companion to Black British History (Oxford, 2007), pp. $\overline{19} \overline{1}-\overline{1} 92$.

\begin{tabular}{|l|}
\hline Formatted: Font: $10 \mathrm{pt}$ \\
\hline Formatted: Font: $10 \mathrm{pt}$ \\
\hline Formatted: Font: $10 \mathrm{pt}$ \\
\hline Formatted: Font: $10 \mathrm{pt}$ \\
\hline Formatted: Font: $10 \mathrm{pt}$ \\
\hline Formatted: Font: $10 \mathrm{pt}$ \\
\hline Formatted: Font: $10 \mathrm{pt}$ \\
\hline Formatted: Font: $10 \mathrm{pt}$ \\
\hline Formatted: $10 \mathrm{pt}$ \\
\hline
\end{tabular}


protracted decline of the British empire over the course of the twentieth century. Similarly the Camp Coffee brand originally featured a label showing a seated Scottish soldier being served coffee on a tray by his standing Sikh servant. The tray was at some point removed, but this essentially servile image persisted until 2006 when the label was altered to show Sikh and Scotsmen sitting down to drink their coffee together ${ }^{13}$.

Although the industrialisation of production coincided with a democratisation of demand, this was not a straightforward process as Rossfeld's contribution makes clear. The comparison with coffee is again instructive here - not least as the two gradually moved from being competitor to complementary products. Interestingly it seems that consumers themselves drove this process in that the attempts of manufacturers to market drinking chocolate to the working classes as a healthier beverage than coffee (or rather its surrogates) largely failed, whereas the use of solid chocolate as a snack food that could be consumed during the working day was successful. Chocolate's lasting connotations as a luxury product perhaps explain why it was the higher quality brands, rather than the "economic" offerings that proved more successful in attracting socially "ascendant” working class consumers.

This demonstration of consumer agency operating within a framework of cultural connotation has important implications for commodity biography. Bruce Robbins, responding to a plethora of popular histories of products and commodities, lamented that these employed a characteristic narrative that traces the ways by which a "plucky little commodity" succeeds in "conquering the world" 14 . This is presented as a triumphant tale of democratization in which the various conservative forces preventing the product reaching the masses - elitist restrictions, state protectionism, and religious prohibitions - are overcome by the commodity's innate qualities, notably its irresistible taste. The often repeated, though as far as I am aware, apocryphal tale of Pope Clement III, being asked to rule that coffee was "the devil's brew", tasting it, and declaring that it so delicious that it would be wise to claim it for Christ' is a perfect example.

In fact, argues Robbins, the reverse is true in that the agency in commodity history lies rather with those humans who perform the cultural work necessary to permit the adoption of the new item into existing practices. Wolfgang Schivelbusch's chapters on coffee and chocolate in his pioneering study of Tastes of Paradise demonstrated how both products were integrated into what he saw as the prevailing ideologies of $18^{\text {th }}$ century European society with coffee presented as emblematic of a new northern, public, protestant bourgeois, work ethic, while chocolate was cast as part of a southern, private, catholic, ancien régime, luxury lifestyle ${ }^{15}$. Although the opposition between the two beverages in this schema is overly stark - both were served publicly and privately by elites throughout Europe -, the importance of manufacturing meaning surrounding their consumption remains clear.

Yet the comment of the Swiss manufacturer, reported by Rossfeld in this issue, that "what many years of expensive propaganda work only very slowly achieved, the war did for us in only a few months" is indicative that rapid adoption is often as much the result of a contingent change in the external context. The same material qualities of the chocolate bar that made it suitable for snack food among industrial workers (the ease of transport, speed of consumption, and rapidly absorbed calorific value) made it a highly effective foodstuff for fighting forces. With its inclusion in army rations, the economic and cultural barriers surrounding chocolate's consumption were removed with the state effectively giving its soldiers no viable choice but to begin consuming it. Köse's dating of the arrival of chocolate as a mass food in Turkey and the

13 “Camp coffee forced to change label by the PC brigade”, Daily Mail, online edition, 11 September 2006.

${ }_{14}$ Bruce ROBBINS, "Commodity Histories", $\bar{P} \bar{M} \bar{L}$ (Proceedings of the Modern Languages Association), vol. 120 no.2 (March 2005), pp.454-463.

15 Wolfgang SCHIVELBUSCH, Tastes of Paradise. A Social History of Spices, Stimulants, and Intoxicants (New York, 1993), pp.15-95.

Formatted: Font: $10 \mathrm{pt}$
Formatted: Font: $10 \mathrm{pt}$
Formatted: Font: $10 \mathrm{pt}$
Formatted: Font: $10 \mathrm{pt}$
Formatted: Font: $10 \mathrm{pt}$
Formatted: Font: $10 \mathrm{pt}$


former Ottoman territories to the wars of 1911-23, during which both sides were supplied by Nestlée, is telling in this regard. Again a similar same story can be told about coffee whose value as both a hot beverage and a stimulant was utilised by American troops during the civil war, European forces during the First World War, and whose soluble forms, first introduced during the Second World War, laid the path for the spread of so-called "instant-coffees" such as Nescafe in the post-war era.

Mitsuda's account of the incorporation of western style confectionary into Japanese consumption is instructive in this regard. Again conflict played a key role with the SinoJapanese (1894-5) and Russo-Japanese (1904-05) wars providing a critical opportunity for western-style confectionary makers who were able to market their products as portable, nourishing foodstuffs, both to the military itself, and relatives keen to despatch gifts to the troops in the field. Mitsuda's observation that it was the healthy, rather than the western, connotations of chocolate that led to its eventual breakthrough in the early $20^{\text {th }}$ century is particularly valuable given the presumption that the adoption of chocolate is simply explained through emulation.

Here again there are interesting points of comparison between the history of coffee and chocolate. Both originally entered Japan through the trading outpost of Dejima with the first shipments of coffee recorded as arriving in the $1690 \mathrm{~s}$, and beans soon being offered as gifts to the prostitutes of Nagasaki who allegedly valued its stimulant qualities as a way of staying awake during their work. Like chocolate, the taste for coffee was initially hindered by the fact that the milk $\mathrm{k}_{2}$ which was customarily added to it by Europeans, was avoided by the Japanese as an animal product. In the end this was overcome by mixing ground coffee with large quantities of sugar to be sold in dried form to be subsequently mixed with hot water ${ }^{16}$.

From the 1880s through to the 1940s many Japanese migrants travelled to Brazil to join the agricultural workforce after the abolition of slavery; and by the 1910s Japanese owned coffeeplantations were beginning to appear. A key figure in this transnational trade was Mizuno Ryu, president of the Imperial Colonial Company of Japan in Brazil ${ }_{2}$ who as well as organizing the transport of workers to Brazil, also established a chain of almost fifty coffee houses in Japan. This model of transnational integration along the commodity chain has been mirrored in the post-war era by companies such as the Ueshima Coffee Company, which owes its fortunes to the introduction of its highly popular "canned coffee" products in Japan in 1969. These are sold from vending machines for consumption at, or on the way to, work, echoing the strategy by which chocolate was marketed as improving job performance in the inter-war era.

The rise of development of integrated companies, and the role of global multi-nationals such as Nestle in the transformation of both the chocolate and coffee industries prompts one final observation, underscored by Schulte-Beerbuehl's contribution $n_{2} \div$ namely the need for greater investigation of the transnational history of the food processing industries which extends beyond technological innovation to examine industrial associations, international collaboration, the imposition of international norms and standards, and so forth. Such studies would help to move our focus beyond the business history of individual firms (which have tended, not least for reasons of archive availability, to focus on larger and more successful concerns) to the evolution of the sector as a whole. While academic approaches to commodity history, as exemplified in the work of Sidney Mintz on sugar, have taught us to think about the ways in which the fortunes of cultivators at the periphery were linked to the behaviour of consumers in the metropole, we are still far less clear about the transnational connections between those manufacturers and producers involved in transforming the commodity into a product, and the ways that these helped to consolidate the global structures within which both 
the chocolate and coffee industries operated ${ }^{17}$. The recent developments in economic sociology surrounding the analysis of global value chains, in particular the recognition of the role of socalled "governance" in establishing the operating practices within these, need to be investigated more fully from a historical perspective ${ }^{18}$. Such an approach might provide a better understanding of the "dark secrets" of the chocolate and coffee industries.

${ }^{17}$ Sidney MINTZ, Sweetness and Power. The Place of Sugar in Modern History (London, 1986).

${ }^{18}$ See Peter GIBBON, Jennifer BAIR and Stefano PONTE, "Governing global value chains: an introduction", Economy and Society, vol. 37 no. 3 (2008), pp.315-338. 